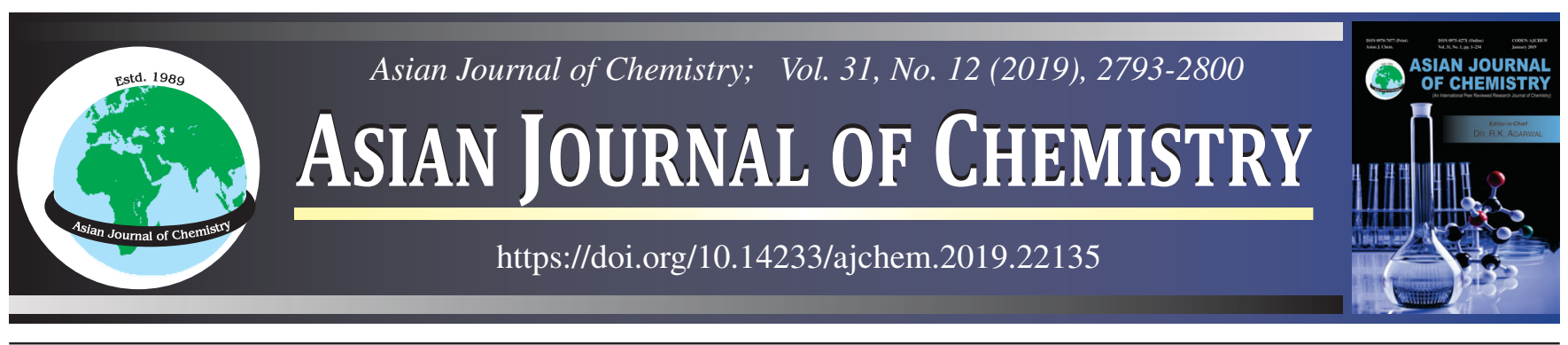

\title{
Validation of Microwave and ICP Parameters for Assessment of Selected Toxic Trace Elements in Fresh Fruits from Turabah Valley of Saudi Arabia
}

\author{
Awad Abdalla Momen ${ }^{1,2, *, \bullet}$, Mohamed Hesham Mahmoud ${ }^{3,4, \bullet}$, Dafaalla Mohammed Hag Ali $^{1,5, \bullet}$, \\ SaAd Hmoud Alotaibi ${ }^{1}$, Mohammed Awad Khalid $^{1,6,0}$ and Malik Abdalla Elsheikh ${ }^{1,5,00}$
}

${ }^{1}$ Department of Chemistry, Turabah University College, Turbah, Saudi Arabia

${ }^{2}$ Department of Chemistry, College of Applied and Industrial Science, University of Bahri, Bahri, Sudan

${ }^{3}$ Department of Chemistry, College of Science, Taif University, Taif, Saudi Arabia

${ }^{4}$ Central Metallurgical Research and Development Institute, Helwan, Egypt

${ }^{5}$ Department of Chemistry, College of Science, Sudan University of Science and Technology, Khartoum, Sudan

${ }^{6}$ Department of Chemistry, College of Science, University of Khartoum, Khartoum, Sudan

*Corresponding author: Fax: +966 1 27274299; E-mail: aamomena@yahoo.com; a.abdelkareem@tu.edu.sa

The analytical parameters of the microwave assisted oven and of the inductively coupled plasma (ICP) method were extensively studied and well validated in terms of spectral lines $(\mathrm{nm})$, linearity $\left(\mathrm{R}^{2}\right)$, accuracy (recovery \%), precision (RSDs), detection and quantification limits (LODs and LOQs). The validated analytical method was used to determine the contents of selected toxic trace elements (TTEs) in fresh fruit samples from Turabah Valley of Saudi Arabia. Samples were digested by a microwave-assisted oven at the ratio of 1:2.5 (v/v) $\left(\mathrm{H}_{2} \mathrm{O}_{2}: \mathrm{HNO}_{3}\right)$. The $\mathrm{R}^{2}>0.9990$ or better, the recovery $(\%)$ were within the acceptable range $(100 \pm 8)$, the RSDs were below $4 \%$, the LODs and the LOQs were ranged between $0.0005-0.0556 \mathrm{mg} \mathrm{kg}^{-1}$ and $0.003-0.174 \mathrm{mg} \mathrm{L}^{-1}$, respectively. It was found that $\mathrm{Al}, \mathrm{Mn}, \mathrm{Pb}, \mathrm{As}$ and $\mathrm{Cd}$ were detected in most analyzed samples, while $\mathrm{Co}, \mathrm{Ni}$ and $\mathrm{Cr}$ were below the detection limits of the method. A considerable variation were observed with regard to TTEs concentrations in different studied fruit samples. TTEs content of fruits were compared with those of soil and well water samples in the same area. Elevated levels of Al were obtained in some fruit samples, while other elements were within the critical safety levels specified by the FAO/WHO/SASO. Some physico-chemical properties such as moisture, ash and total solid contents $(\%)$ of fruits were also estimated and compared with the reference values. The results indicate that the developed ICP method was well suited for determination of toxic and/or nutrient trace elements in fruits and possibly similar matrices.

Keywords: ICP parameters, Toxic trace elements, Fresh fruits, Turabah valley.

\section{INTRODUCTION}

Sample preparation is of great importance for obtaining desirable results. Wet and/or dry ashing procedures are quite slow making it difficult to follow consistently [1]. Recently, microwave techniques have become more popular in the digestion of various food samples. Since they provide simple and rapid dissolution of sample matrices allowing for the powerful extraction of elements from samples. In addition, they require low oxidizing reagent volumes, cause less contamination and prevent the volatilization of elements.
In literature, different techniques have been reported for the analysis of trace elements in different food matrices including fruits. There are many factors affecting the choice for an analytical technique. These include the susceptibility to matrix effects, detection limits and the suitability for matrix of interest. Historically, atomic absorption spectrophotometers (AAS) have been the instruments of choice for most fruit analysis, but recently, inductively coupled plasma-optical emission spectrometry (ICP-OES) has been used frequently by many researchers because it provides fast, rugged and multi-element analysis in a single solution [1]. Hence, the analytical parameters of the

This is an open access journal, and articles are distributed under the terms of the Attribution 4.0 International (CC BY 4.0) License. This license lets others distribute, remix, tweak, and build upon your work, even commercially, as long as they credit the author for the original creation. You must give appropriate credit, provide a link to the license, and indicate if changes were made. 
ICP method must be extensively studied and well adopted for precise and accurate measurements.

The effect of toxic trace elements (TTEs) contamination of fruits cannot be underestimated, as this food source is an important component of human diet. Different elements are present in the human diet that are necessary for good health. However others may cause acute toxicity. For instance, calcium is necessary for the proper development of bone and teeth and plays an important role in glucose and protein absorption [2]. The toxicity of some elements like lead and cadmium can reduce mental and central nervous function and damage many organs. For this reason, a large number of studies have been undertaken to identify the potential risk factors with TTEs in different food matrices $[3,4]$.

Fruits are important edible crops and are an essential part of the human diet. They are rich in nutrients required for human health, and are an important source of carbohydrates, vitamins, minerals, and fibers. Furthermore, fruits can potentially be contaminated with TTEs from water or soil (by fertilizers or pesticides) or through air (by vehicles or generators exhausts or mining and industrial activates) [5]. A great effort has been expended on developing analytical methods for determination of TTEs in food matrices [6,7]. Many studies in literature were attempt to assess the nutritional benefits and potential risks arising from the consumption of fruits. Yami et al. [5] have studied selected nutrients and toxic metals in fruits from Ethiopia. Radwan and Salama [8] have reported heavy metal content in fruits and vegetables in Egypt. Sager [9] was able to determine the main and trace element contents of tomatoes grown in Austria. Todea et al. [10] have studied the level from major-to-trace elements in different apple cultivars in Romania. Abdrabo et al. [11] have determined 23 elements in Spanish palm dates. Basha et al. [4] have reported trace elements in vegetables and fruits cultivated in India. Taharn et al. [12] have investigated the concentration of major to trace elements in tomato varieties economically grown in the northeast of Thailand. Mausi et al. [13] have conducted a study on the assessment of selected heavy metal concentrations in selected fresh fruits in Kenya. Bressy et al. [14] have determined the trace element concentrations in tomato samples at different stages of maturation in Brazil. Igwegbe et al. [15] have reported a survey of heavy metal contents of selected fruit and vegetable crops in Nigeria. Ali and Al-Qahtani [16] have studied the content of heavy metals in fruits from Saudi Arabian markets. Aldjain et al. [17] have determined the concentration of heavy metals in the fruit of date palm growing at different locations of Riyadh, Saudi Arabia.
Based on several behaviours like probability of potential toxicity effects by toxic trace elements in human diets because of the consumption of fruits. This requires an excessive assessment of fruit contents to ensure that their levels meet the standards that are agreed by local and international authorities like Food and Agriculture Organization (FAO), World Health Organization (WHO) and Saudi Arabian Standard Organization (SASO). Therefore, the aims of the present work were undertaken for the first time to study and to develop and to validate the microwave assisted oven and ICP parameters for the determination of selected eight TTEs i.e., $\mathrm{Al}, \mathrm{Ni}, \mathrm{Co}, \mathrm{Mn}$, $\mathrm{Cr}, \mathrm{Pb}$, As and $\mathrm{Cd}$ in fresh fruits date palm (rutab), cantaloupe melon, watermelon, lemon, mandarin, pomegranate, grape and tomatoes) from Turabah valley of Saudi Arabia. In addition, we also focused to understand the ecological and the environmental relationship between TTEs contents in fruits with those found in agricultural soil and well water samples from the same area due to the presence of elevated levels of $\mathrm{Al}$ in soil samples from Turabah Valley $[5,18]$. In addition, a comparative study for some physico-chemical properties such as moisture contents (\%), ash contents (\%) and total solid contents (\%) were also estimated and compared by the reference values for nutritive purposes.

\section{EXPERIMENTAL}

A microwave digestion system (Model MARS-5, CEM corporation, Matthews, USA) programmable for time and power between 800-1600 Watts, equipped with 12 high pressure Teflon vessels (Model Easy Prep xp-1500 plus, CEM corporation, Matthews, NC, USA) were used for sample digestions. The heating programs of the digestion system are shown in Table-1. In addition, a quadruple Elan DRC II (PerkinElmer Life and Analytical Sciences, Shelton, CT, USA) ICP-OES (Perkin Elmer Model Optima 2100 DV, USA) with CCD detector was used in this study for standards and samples analysis. The operating conditions of ICP-OES are also indicated in Table-1. These conditions were carefully selected and well optimized in order to maximize the sensitivity for the desired elements and to obtain the best precision and accuracy. Moreover, some instrumental operating conditions of MARS-5 and ICP-OES were set according to manufacturer guidelines.

All the reagents were of the highest commercially available purity grade. Ultrapure deionized distilled water (UDDW), (18 $\mathrm{M} \Omega / \mathrm{cm}$ ) was obtained from a Milli-Q Plus water purification system (Millipore Inc., Paris, France) and used throughout the experiments. Hydrogen peroxide $\left(30 \%, \mathrm{~d}=1.11 \mathrm{~kg} \mathrm{~L}^{-1}\right)$ and

TABLE-1

HEATING PROGRAM OF MARS-5 FOR DIGESTION OF FRESH FRUIT SAMPLES AND THE INSTRUMENTAL CONDITIONS OF ICP-OES

\begin{tabular}{|c|c|c|c|}
\hline \multicolumn{2}{|c|}{ Heating program of MARS- 5} & \multicolumn{2}{|c|}{ Instrumental conditions of the ICP-OES } \\
\hline Parameters & Values & Parameters & Values \\
\hline Temperature $^{\mathrm{a}}$ & $220\left({ }^{\circ} \mathrm{C}\right)$ & RF incident power ${ }^{a}$ & 1600 (Watts) \\
\hline Pressure & 800 (pis) & Frequency & $40.68(\mathrm{MHz})$ \\
\hline Ramp time & $25(\min )$ & Nebulizer argon flow rate ${ }^{a}$ & $0.60\left(\mathrm{~L} \mathrm{~min}^{-1}\right.$, Argon $)$ \\
\hline Holding time & $10(\min )$ & Plasma argon flow rate & $15.0\left(\mathrm{~L} \mathrm{~min}^{-1}\right.$, Argon $)$ \\
\hline Ventilation & $10(\mathrm{~min})$ & Auxiliary argon flow rate & $0.2\left(\mathrm{~L} \mathrm{~min}^{-1}\right.$, Argon $)$ \\
\hline Acid/oxidant mixture ${ }^{a}$ & $2.0 \mathrm{~mL} \mathrm{H}_{2} \mathrm{O}_{2}(30 \%) / 5.0 \mathrm{~mL} \mathrm{HNO}_{3}(65 \%)$ & Sample uptake flow rate ${ }^{a}$ & $2.0\left(\mathrm{~mL} \mathrm{~min}^{-1}\right)$ \\
\hline
\end{tabular}

${ }^{a}$ Optimized value 
$65 \% \mathrm{HNO}_{3}\left(\mathrm{~d}=1.40 \mathrm{~kg} \mathrm{~L}^{-1}\right)$, [Merck, Germany] were used as received for digestion of fruit samples. High-purity grade $\mathrm{V}$ (Atomic Spectroscopy Standard Solution) consist of lead (2 $\left.\mathrm{mg} \mathrm{L}^{-1}\right)$, cadmium $\left(5 \mathrm{mg} \mathrm{L}^{-1}\right)$, arsenic and chromium $(10 \mathrm{mg}$ $\left.\mathrm{L}^{-1}\right)$, manganese $\left(15 \mathrm{mg} \mathrm{L}^{-1}\right)$, nickel $\left(40 \mathrm{mg} \mathrm{L}^{-1}\right)$, cobalt $(50 \mathrm{mg}$ L-1) and aluminium (200 $\mathrm{mg} \mathrm{L}^{-1}$ ) was purchased from PerkinElmer, USA). This solution was used for preparing standards for calibration curves and spiking of some samples for recovery test. The purity of argon and nitrogen gases used in this study were greater than $99.99 \%(\mathrm{v} / \mathrm{v})$. All laboratory glassware were soaked in $10 \%$ (v/v) $\mathrm{HNO}_{3}$ for $24 \mathrm{~h}$, rinsed several times with ultrapure deionized distilled water and dried in a microwave oven (isik, GORKEM Co., Ltd, Turkey).

Sampling and preservation: A total of 42 fresh fruit samples, namely date palm (rutab, wet stage of fruit), lemon, cantaloupe melon, watermelon, mandarin, grape, pomegranate and tomatoes were collected from the local vegetable and fruit markets in Turabah province (Saudi Arabia). The informations of the studied fruit samples are indicated in Table-2. Samples were collected in clean polyethylene containers according to their types. Surface contaminants of the fruits were washed first with tap water, rinsed UDDW and dried with tissue paper, then preserved in the refrigerator prior to processing for drying. After a while, each sample was cut separately with clean stainless steel knife into small pieces (2-3 mm size), well mixed and dried at $90{ }^{\circ} \mathrm{C}$ in microwave oven until constant weight was achieved [19]. Three dried samples of each type were mixed, subsequently grounded into a fine powder and homogenized using a clean commercial kitchen grinder (Philips, Indonesia). The grounded samples were properly labeled and stored in polyethylene containers at $-20^{\circ} \mathrm{C}$ until needed for analysis.

Digestion of fruits: For determination of moisture content $(\%)$, a portion of the sample from each sample was weighed accurately using $0.01 \mathrm{mg}$ sensitive weighing analytical balance in a clean dried porcelain crucible, then dried at $90{ }^{\circ} \mathrm{C}$ in a microwave oven until constant weight was obtained [19]. For sample digestions, about $0.5 \mathrm{~g}$ of each dried sample was weighed accurately into dry clean PTFE digestion vessel and inserted directly into a dry and clean Teflon separate microwave assisted digestion vessel. About $2.0 \mathrm{~mL} \mathrm{H}_{2} \mathrm{O}_{2}(30 \%)$ and $5.0 \mathrm{~mL} \mathrm{HNO}_{3}$ $(65 \%)$ in the ratio of 1:2.5 were added dropwise to each sample. The contents were shaken carefully, then the digestion vessels were closed and the optimized heating programs were followed (Table-1). After digestion, clear solutions were cooled down to room temperature and reactors were opened to eliminate nitrous vapours if any. Then, the interior walls of vessels were washed down with UDDW and vessels were swirled through the digestion to keep the wall clean and to prevent the loss of the samples as much as possible. Then, the contents of vessels were quantitatively transferred to $50 \mathrm{~mL}$ volumetric flask and diluted to the mark with DDW. This procedure was approximately similar to that stated in previous work [20] and partly modified from that recommended by Bressy et al. [21], with some modifications in the reagent volumes and the microwave assisted heating program.

Several analytical blanks consisting of DDW/ $\mathrm{H}_{2} \mathrm{O}_{2} / \mathrm{HNO}_{3}$ were also prepared in the same way as the samples and analyzed to characterize instrumental drift. The digests were prepared three times for each sample. To avoid cross-contamination, all vessels were carefully cleaned with $10 \%(\mathrm{v} / \mathrm{v}) \mathrm{HNO}_{3}$ solution before to proceed with the sample digestion. In addition, for safety purposes, sample and blank solutions were prepared in a Class-100 laminar flow hood. The optimizations were based on production of clear solutions, shorter digestion time, minimum reagent volumes, small samples weight and suitable heating program.

Calibrations: Standard solutions were prepared in $\mathrm{HNO}_{3}$ (65\%) by diluting a multi-elemental standard solution containing the analyte elements. Reagent blanks were prepared in the same manner as standards. Under the optimized conditions, seven concentrations $\left(\mathrm{mg} \mathrm{L}^{-1}\right)$ of working standards within the linear dynamic range of ICP-OES were measured, and the calibration curves for each analyte element were plotted.

Analyses of fruits: The moisture contents (\%) and the total sold contents $(\%)$ of fruits were determined after drying in a microwave oven at $90^{\circ} \mathrm{C}$ until constant weight [19]. In addition, the ash contents $(\%)$ of fruits were also determined after ashing in a muffle furnace (Stuart Scientific Co. Ltd., England) set at $550^{\circ} \mathrm{C}$ for $2 \mathrm{~h}$. Standard solution was diluted with UDDW for calibration standards. All standards and sample solutions were analyzed three times on a simultaneous Varian 710 ES axial ICP-OES with CCD detector. A Cetac auto sampler with 15 $\mathrm{mL}$ sample tubes was connected to the peristaltic pump. A Burgener Teflon Mira Mist-nebulizer (SCP Science) and glass cyclonic spray chamber were used for sample introduction.

TABLE-2

DETAILS OF THE STUDIED FRESH FRUIT SAMPLES COLLECTED FROM TURABAH VALLEY OF SAUDI ARABIA

\begin{tabular}{lllc}
\hline Fruits (English name) & Fruits (Scientific name) & Part investigated & Number of samples \\
\hline Date palm (rutab) & Phoenix dactylifera L. & Edible tissues & 9 \\
Cantaloupe melon & Cucumis melo L. & Edible tissues & 3 \\
Watermelon (i) $^{\mathrm{b}}$ & Citrullus lanatus L. & Edible tissues & 3 \\
Watermelon (ii) & Citrullus lanatus $\mathrm{L}$. & Edible tissues & 3 \\
Lemon & Citrus limonum L. & Whole & 6 \\
Grapes $($ i) & Vitis vinifera L. & Whole & 3 \\
Grapes (ii) & Vitis vinifera L. & Whole & 3 \\
Mandarin & Citrus reticulate L. & Edible tissues & 3 \\
Pomegranate & Punica granatum L. & Edible tissues & 3 \\
Tomatoes & Solanum lycopersicum L. & Whole & 6 \\
\hline
\end{tabular}

Total samples $=42$

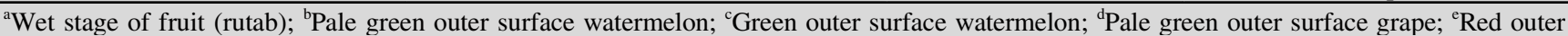
surface grape 
Statistical analysis: The results were statistically evaluated by ANOVA test and Student t-test, $(\mathrm{P}=0.05)$, in addition, Microsoft Excel and Origin software's were also used. The obtained concentrations were expressed as average value \pm confidence interval (at $95 \%$ confidence interval). All statistical analysis were based upon triplicate measurements.

Validation of ICP method: To evaluate the analytical method proposed for the TTEs analysis of fruits by ICP based techniques, some analytical figures of merit were estimated, such as spectral emission lines (wavelengths), linearity, accuracy and precision, limits of detection (LOD) and limit of quantification (LOQ). The analytical wavelengths ( $\mathrm{nm}$ ) were set at two different spectral primary (atomic) and secondary (ionic) lines for each analyte. The linearity as a square correlation coefficient $\left(\mathrm{R}^{2}\right)$ for each analyte was determined by preparing the calibration curve using non-weighted least-squares linear regression line. The accuracy of the method as a recovery (\%) was determined by spiking some fruit samples with different concentration levels of standard solution (before and after digestion steps) and passed through the same digestion procedure. The precision of the method was estimated by means of the relative standard deviation (RSD). The RSDs were calculated from the elemental concentrations obtained after the analysis of five independent replicates of each sample.

\section{RESULTS AND DISCUSSION}

Selection of spectral lines: All analytes were measured in two different spectral emission lines (atomic and ionic). The criteria of selection between them were based on the sensitivity, the spectral interferences and the concentration range of each analyte. In all cases, the sensitivities were calculated at spectral lines of less interferences (with high sensitivity). The selected line $(\mathrm{nm})$ for each element was indicated in Table-1.

Optimization of microwave parameters: The effectiveness of samples digestion was depend on the sample matrix, so, it is important to optimize the microwave oven parameters. The microwave oven temperature and acid/oxidant digestion mixture have the greater effects on samples digestion, while pressure, ramp, holding and the ventilation time have relatively small effects on samples digestion. The microwave oven temperature was set between $210-250^{\circ} \mathrm{C}$. A clear solution was observed at $220^{\circ} \mathrm{C}$. Therefore an oven temperature at $220^{\circ} \mathrm{C}$ was used in this study. Moreover, the acid/oxidant mixture $\left(\mathrm{H}_{2} \mathrm{O}_{2} / \mathrm{HNO}_{3}\right)$ in the ratio of 1:1, 1:2, 1:25, 1:3 and 1:3.5 were studied. A clear solution was observed at 1:2.5 ratio. Therefore, the ratio of 1:2.5 was used for samples digestion throughout this study. The optimized values for microwave oven parameters were presented in Table- 1 .

Optimization of ICP parameters: Since signal intensities of each analyte depend on the sample matrix, it is important to optimize the ICP parameters. As emission intensities are mostly affected by radio frequency (RF) incident power, nebulizer argon gas flow rate and sample uptake flow rate that have a greater impact upon the sensitivity of measurement. Whereas frequency, plasma argon gas flow rate and auxiliary argon gas flow rate have relatively small effects on sensitivity and are usually adjusted to accommodate memory effects due to particular sample type such as organic materials and/or dissolved solids [22]. The radio frequency (RF) incident power was studied in the range 1400-1700 watts. The results indicate that the sensitivity and the linearity are better at 1600 watts for almost all analytes and the stability of plasma was improved. In addition, the effect of nebulizer argon gas flow rate was studied between $0.40-0.80 \mathrm{~L} \mathrm{~min}^{-1}$. A maximum intensity at $0.60 \mathrm{~L} \mathrm{~min}^{-1}$ for all analytes was observed, thus a $0.60 \mathrm{~L} \mathrm{~min}^{-1}$ nebulizer argon gas flow rate was adopted throughout this study, which provides high sensitivity and good precision. Moreover, the sample uptake flow rate was investigated at three levels: 1.0, 2.0 and $3.0 \mathrm{~mL}$ $\mathrm{min}^{-1}$. It was found that the emission intensities for $\mathrm{As}, \mathrm{Cd}$, and $\mathrm{Pb}$ were higher at $1.0 \mathrm{~mL} \mathrm{~min}^{-1}$ uptake flow rate, while for $\mathrm{Al}, \mathrm{Cr}, \mathrm{Co}$, and $\mathrm{Mn}$ the uptake flow rates were slightly higher at $2.0 \mathrm{~mL} \mathrm{~min}^{-1}$ and only for $\mathrm{Ni}$ the intensity was higher at 3.0 $\mathrm{mL} \mathrm{min}{ }^{-1}$. Therefore, sample uptake flow rate of $2.0 \mathrm{~mL} \mathrm{~min}^{-1}$, which provide sufficient sensitivity and low sample consumptions, was chosen as optimal and applied for the determinations throughout this study.

Analytical figures of merit: The selected spectral lines that gives high sensitivities and maximum emission intensities under the optimal ICP operating conditions were described in Table-3. Moreover, the method linearity using the selected analytical line was tested at five concentrations within 0.04$100 \mathrm{mg} \mathrm{L}^{-1}$ was satisfactory for all the analytes with the correlation coefficients $\left(\mathrm{R}^{2}\right)$ higher than 0.9990 in linear regression. This confirmed the linearity of the analytical method followed in accordance with criteria that specified by AOAC $[23,24]$. The method accuracy of each analyte was calculated as a recovery $(\%)$, and it was found to be within the acceptable range [100 \pm 8 for all estimated elements] (Table-3). This indicate that there were no significant losses or gained for analytes by the followed analytical technique. In addition, the precision of ICP method was calculated as a relative standard deviation (RSD) of five independent replicates of each sample. It was found to be below $4 \%$ (Table-3). Furthermore, this value confirmed that was good precision of the following method. Moreover, the LODs and LOQs methods for the tested elements were determined by analyzing seven portions of standard solutions simultaneously following the general procedure. The LOD and LOQ of each analyte were calculated as follows [25]:

$$
\begin{aligned}
\mathrm{LOD} & =\frac{3 \sigma}{\mathrm{m}} \\
\mathrm{LOQ} & =\frac{10 \sigma}{\mathrm{m}}
\end{aligned}
$$

whereas, LOD is the limit of detection, LOQ is the limit of quantification, $\sigma$ is the standard deviation of intensity of seven blanks and $\mathrm{m}$ is the slope of calibration curve for each element. The LODs $\left(\mathrm{mg} \mathrm{kg}^{-1}\right)$ of elements were ranged between 0.0005 $0.0556 \mathrm{mg} \mathrm{kg}^{-1}$ for $\mathrm{Mn}$ and $\mathrm{Al}$ respectively, while LOQs ( $\mathrm{mg}$ $\mathrm{kg}^{-1}$ ) were ranged between $0.003 \mathrm{mg} \mathrm{L}^{-1}$ for Co and $0.174 \mathrm{mg} \mathrm{L}^{-1}$ for $\mathrm{Al}$ (Table-3). The values of LODs and LOQs clearly demonstrated the high sensitivity and the linear range of ICP method.

Moisture content (\%): The total water component of a sample is described as the moisture content (\%) of food sample. It is used to determine the storage capacity and the quality of food sample. For moisture content (\%) determination a three crucibles were oven dried at $90{ }^{\circ} \mathrm{C}$ for $30 \mathrm{~min}$ and transferred 


\begin{tabular}{|c|c|c|c|c|c|c|}
\hline \multicolumn{7}{|c|}{$\begin{array}{c}\text { TABLE-3 } \\
\text { ANALYTICAL VALUES OF MERITS OF ICP METHOD }\end{array}$} \\
\hline Elements & $\begin{array}{l}\text { Wavelengths } \\
(\mathrm{nm})\end{array}$ & $\begin{array}{c}\text { Correlation } \\
\text { coefficients }\left(\mathrm{R}^{2}\right)\end{array}$ & RSDs (\%) & $\begin{array}{c}\text { Spiking } \\
\text { recoveries }(\%)\end{array}$ & $\begin{array}{c}\text { LODs } \\
\left(\mathrm{mg} \mathrm{kg}^{-1}\right)\end{array}$ & $\begin{aligned} \text { LOQs } \\
\left(\mathrm{mg} \mathrm{kg}^{-1}\right)\end{aligned}$ \\
\hline $\mathrm{Al}$ & 308.212 & 0.9993 & 3.15 & $106 \pm 4$ & 0.0556 & 0.174 \\
\hline $\mathrm{Ni}$ & 231.604 & 0.9991 & $\mathrm{NC}$ & $106 \pm 5$ & 0.0011 & 0.004 \\
\hline $\mathrm{Co}$ & 238.892 & 0.9997 & $\mathrm{NC}$ & $95 \pm 3$ & 0.0008 & 0.003 \\
\hline $\mathrm{Mn}$ & 257.610 & 0.9993 & 2.22 & $108 \pm 6$ & 0.0005 & 0.006 \\
\hline $\mathrm{Cr}$ & 267.716 & 0.9996 & 2.11 & $100 \pm 4$ & 0.0012 & 0.042 \\
\hline $\mathrm{Pb}$ & 220.353 & 0.9997 & 2.98 & $98 \pm 5$ & 0.0062 & 0.086 \\
\hline As & 188.979 & 0.9998 & 1.01 & $102 \pm 5$ & 0.0054 & 0.016 \\
\hline $\mathrm{Cd}$ & 226.502 & 0.9990 & 2.83 & $104 \pm 3$ & 0.0007 & 0.019 \\
\hline
\end{tabular}

Results were expressed as mean \pm standard deviation; $\mathrm{R}^{2}=$ correlation coefficient; $\mathrm{LOD}=$ limit of detection; $\mathrm{LOQ}=$ limit of quantification

into desiccators to cool down. After cooling, $5 \mathrm{~g}$ of each of the samples were weighed in the crucible and then oven dried at $90{ }^{\circ} \mathrm{C}$ to a constant weight. The percentage values for the moisture contents $(\%)$ calculated using the formula [19]:

$$
\text { Moisture content }(\%)=\frac{\mathrm{W}_{3}-\mathrm{W}_{1}}{\mathrm{~W}_{2}-\mathrm{W}_{1}} \times 100
$$

whereas, $\mathrm{W}_{1}, \mathrm{~W}_{2}$ and $\mathrm{W}_{3}$ are the weight of crucible, weight of crucible and sample before drying and weight of crucible and sample after drying, respectively.

The moisture content (\%) of fruits obtained in this study and those found in literature were indicated in Table-4. It was observed that moisture content (\%) was lower for date palms (rutab) and higher for tomatoes, but the differences were not significant because all the fruits were still fresh when purchased from the market. Moisture content (\%) influences the activities of microorganisms during storage. The higher the moisture content (\%), the more susceptible the sample will be to microbial attack. In addition, increase in moisture content (\%) reduces the proximate principles such as fat, protein and carbohydrate. thereby decreasing the energy value [26]. The obtained results were generally comparable to those reported in literature previously with some variations related to fruit variety and agroclimatic and environmental conditions.

Total solid content $(\%)$ : Total solid content $(\%)$ is a measure of the amount of material remaining after all the water has been evaporated. The percentage values for the total solid contents (\%) calculated using the formula:

Total solid content $(\%)=100-$ Moisture content $(\%)$
As can be seen in Table-4, the total solid contents (\%) was low for tomatoes $(5.5 \%)$ and high for date palm (rutab) $(88.2 \%)$. The order of total solid contents $(\%)$ in the fruits is date palm (rutab) $>$ grape (ii) $>$ grape (i) $>$ mandarin $>$ lemon $>$ cantaloupe melon $>$ watermelon (ii) $>$ pomegranate $>$ watermelon (i) $>$ tomatoes. These values are approximately comparable with literature values.

Ash content (\%): The fruit ash was determined as total inorganic matter (residue) that remains after organic matter has been burnt off [19]. Different studies have shown the variations in ash contents (\%) in different fruits. High total ash content (\%) for a food material signifies the presence of adulterants [26]. For determination of ash contents (\%), crucibles were dried in a microwave oven at $90{ }^{\circ} \mathrm{C}$ until constant weight and then transferred into the desiccators to cool down. About $5 \mathrm{~g}$ of each of the samples were weighed into the crucible and heated in a muffle furnace set at $550^{\circ} \mathrm{C}$ for $2 \mathrm{~h}$ after which the crucibles were transferred into desiccators then cooled and weighted. The percentage values for the ash contents (\%) calculated using the formula:

$$
\text { Ash content }(\%)=\frac{\mathrm{W}_{3}-\mathrm{W}_{1}}{\mathrm{~W}_{2}-\mathrm{W}_{1}} \times 100
$$

where $\mathrm{W}_{1}, \mathrm{~W}_{2}$ and $\mathrm{W}_{3}$ are the weight of crucible, weight of crucible and sample before ashing and weight of crucible and sample after ashing, respectively.

The ash content (\%) of a biological material is the organic residue that remains after organic matter has been burnt. Ash contents $(\%)$ were determined to assess their nutritive value of fruits. The obtained values in this study and those found in

TABLE-4

PROXIMATE MOISTURE AND TOTAL SOLID CONTENTS (\%) OF FRESH FRUIT SAMPLES

\begin{tabular}{lllc}
\hline \multirow{2}{*}{ Fruits } & \multicolumn{1}{c}{ Moisture contents (\%) } & \multicolumn{1}{c}{ Ash content (\%) } \\
\cline { 2 - 3 } & \multicolumn{1}{c}{ Found } & \multicolumn{1}{c}{ Literature values } & $3.8 \pm 0.7^{\mathrm{c}}$ \\
\hline Date palm (rutab) & $21.8 \pm 0.69^{\mathrm{a}}$ & 21.9 [Ref. 27], 22.8 [Ref. 28] & $1.2 \pm 0.2^{\mathrm{d}}$ \\
Cantaloupe melon & $90.0 \pm 1.34^{\mathrm{b}}$ & 92.5 [Ref. 29], 87.5 [Ref. 30] & $1.3 \pm 0.3^{\mathrm{d}}$ \\
Watermelon (i) & $93.1 \pm 1.90^{\mathrm{b}}$ & 95.4 [Ref. 29], 89.6 [Ref. 30] & $1.5 \pm 0.3^{\mathrm{d}}$ \\
Watermelon (ii) & $92.3 \pm 1.03^{\mathrm{b}}$ & 95.4 [Ref. 29], 89.6 [Ref. 30] & $0.6 \pm 0.03^{\mathrm{d}}$ \\
Lemon & $88.5 \pm 1.98^{\mathrm{b}}$ & 85.1 [Ref. 31] & $0.57 \pm 0.04^{\mathrm{e}}$ \\
Grape (i) & $85.4 \pm 1.76^{\mathrm{b}}$ & 83.0 [Ref. 5], 89.1 [Ref. 24], 90.4 [Ref. 29] & $0.72 \pm 0.06^{\mathrm{e}}$ \\
Grape (ii) & $84.6 \pm 1.81^{\mathrm{b}}$ & 83.0 [Ref. 5], 82.5 [Ref. 24], 79.15 [Ref. 29] & $0.42 \pm 0.02^{\mathrm{e}}$ \\
Mandarin & $87.2 \pm 1.56^{\mathrm{b}}$ & 88.4 [Ref. 5], 88.0 [Ref. 24] & $0.46 \pm 0.02^{\mathrm{e}}$ \\
Pomegranate & $83.0 \pm 1.88^{\mathrm{b}}$ & 89.6 [Ref. 26], 79.80-80.5 [Ref. 32], 84.6 [Ref. 33] & $0.65 \pm 0.05^{\mathrm{e}}$ \\
Tomatoes & $94.5 \pm 1.49^{\mathrm{b}}$ & 93.6 [Ref. 34] & \\
\hline Resul
\end{tabular}

Results were expressed as mean \pm standard deviation, ${ }^{\text {a, b, c, d }}$ means in the same column followed by the same letter are not significantly different at $95 \%$ confidence level, while those with different letters are significantly different 
literature were shown in Table-4. It was observed that ash (\%) was lower for date palm (rutab) and higher for tomatoes. The obtained results were generally comparable to those reported in literature previously with some variations related to fruit variety and agro-climatic and environmental conditions.

TTEs contents: The developed and validated analytical ICP method was employed for the determination of $\mathrm{Al}, \mathrm{Ni}$, $\mathrm{Co}, \mathrm{Mn}, \mathrm{Cr}, \mathrm{Pb}, \mathrm{As}$ and $\mathrm{Cd}$ in 10 varieties of the most commonly fresh fruits in Turabah province and other regions in Saudi Arabia. The average concentrations (mean $\pm \mathrm{SD}, \mathrm{mg} \mathrm{kg}^{-1}$ dry weight) of TTEs were shown in Table-5. In the whole, TTEs contents of the analyzed samples showed highest amount of Al in cantaloupe melon $\left(0.917 \pm 0.072 \mathrm{mg} \mathrm{kg}^{-1}\right)$ and watermelon (i) $(0.878 \pm 0.091)$, while $\mathrm{Al}$ was not detected (ND) in watermelon (ii), lemon, grape (ii) and tomatoes due to below the LOD of ICP method. Furthermore, $\mathrm{Mn}$ was detected in tomatoes $\left(0.016 \pm 0.004 \mathrm{mg} \mathrm{kg}^{-1}\right)$ and grape (ii) $(0.024 \pm 0.006)$, but ND in other samples due to below the LOD of ICP method. Chromium was detected in very low concentrations in grapes (ii) only at $0.005 \pm 0.001 \mathrm{mg} \mathrm{kg}^{-1}$. Moreover, Co and Ni were not detected (ND) in all studied samples because they are below the LOD of ICP method. As unexpected $\mathrm{Cd}$, $\mathrm{As}$ and $\mathrm{Pb}$ were found in most studied fruit samples but with very low concentrations $\left(\sim 0.031 \pm 0.001 \mathrm{mg} \mathrm{kg}^{-1}, \sim 0.049 \pm 0.005 \mathrm{mg} \mathrm{kg}^{-1}\right.$ and $\sim 0.039 \pm 0.006 \mathrm{mg} \mathrm{kg}^{-1}$, respectively). Furthermore, moderately highest concentrations of TTEs were recorded in watermelon (i), grape (i) and mandarin, while the lowest one were recorded in lemon. Moreover, present results (Table-5) revealed that a considerable variations were observed with regards to element concentrations in different studied fruits (Fig. 1). The differences were significant for different samples at $95 \%$ confidence level. In general, present results are in close agreement with those of reported in literature [5,8-17,27]. In addition, FAO/WHO/ SASO has set a limit for heavy metal intake based on body weight for an average adult ( $60 \mathrm{Kg}$ body weight). It was found that our estimated concentrations of all studied elements were within the critical levels specified by the FAO/WHO/SASO. The variation in TTEs concentrations in different fruits samples may be related to variation in texture, structure, chemical and mineral composition of soil. In addition, the morphology of fruits influence the dust deposition and hence different patterns

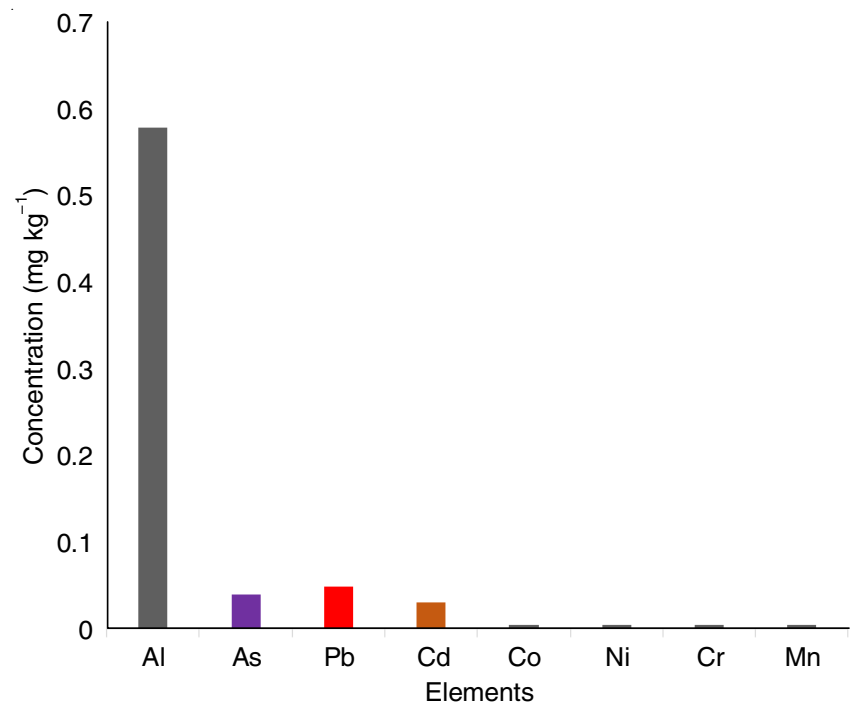

Fig. 1. A bar plot of TTEs average contents in fruits

were observed for elemental concentrations in plant tissues and their fruits. The bioaccumulation of trace elements in the fruits of plants is the combined results of uptake processes via the roots from soil.

Comparison of TTEs contents: Plants are long-lived organisms, which can take up trace elements from the soil, water or air, and retain them for a long time. These elements may enter the human body through consumption of fruits grown in contaminated soil. Therefore, the average contents of TTEs of soil $\left(\mathrm{mg} \mathrm{Kg}^{-1}\right)$ and irrigation water $\left(\mathrm{mg} \mathrm{L}^{-1}\right)$ samples from the same area were compared with present results (Table-6) $[18,29]$. Fig. 2 showed the bar plot of TTEs average contents in fruits compared with those found in agricultural soil and wells water samples from the same area. As expected, Al had the highest concentrations in fruit, agricultural soil and well water samples, while the opposite was observed for all the other elements. Therefore, the presence of $\mathrm{Al}$ in this area must be strictly revised in coming future. Cadmium is readily available for uptake by plants as there is a clear association between $\mathrm{Cd}$ concentration in soil and the plants grown on soil. The guideline value for $\mathrm{Cd}$ in soil from plant uptake is $1 \mathrm{mg} \mathrm{kg}^{-1}$ dry soil weight [35]. As Pb is not being translocated readily in plants,

TABLE-5

AVERAGE CONCENTRATIONS OF TTES IN TEN VARIETIES OF FRUIT SAMPLES

\begin{tabular}{|c|c|c|c|c|c|c|c|c|}
\hline \multirow{2}{*}{ Fruits } & \multicolumn{8}{|c|}{ Concentration ( $\mathrm{mg} \mathrm{Kg}^{-1}$ dry weight, edible portion) } \\
\hline & $\mathrm{Al}$ & $\mathrm{Cd}$ & As & $\mathrm{Pb}$ & $\mathrm{Mn}$ & $\mathrm{Cr}$ & Co & $\mathrm{Ni}$ \\
\hline Date palm (rutab) & $0.118 \pm 0.054^{\mathrm{a}}$ & $0.033 \pm 0.002^{c}$ & $0.068 \pm 0.005^{\mathrm{d}}$ & ND & ND & ND & ND & ND \\
\hline Cantaloupe melon & $0.917 \pm 0.072^{b}$ & $0.030 \pm 0.001^{\mathrm{c}}$ & $0.084 \pm 0.006^{\mathrm{d}}$ & ND & ND & ND & ND & ND \\
\hline Watermelon (i) & $0.878 \pm 0.091^{\mathrm{b}}$ & $0.029 \pm 0.001^{\mathrm{c}}$ & $0.081 \pm 0.004^{\mathrm{d}}$ & $0.077 \pm 0.005^{\mathrm{e}}$ & ND & ND & ND & ND \\
\hline Watermelon (ii) & ND & $0.032 \pm 0.002^{\mathrm{c}}$ & ND & $0.083 \pm 0.006^{\mathrm{e}}$ & ND & ND & ND & ND \\
\hline Lemon & ND & $0.030 \pm 0.001^{\mathrm{c}}$ & ND & $0.031 \pm 0.001^{f}$ & ND & ND & ND & ND \\
\hline Grape (i) & $0.947 \pm 0.088^{b}$ & $0.032 \pm 0.001^{\mathrm{c}}$ & ND & $0.043 \pm 0.003^{f}$ & ND & $0.005 \pm 0.001$ & ND & ND \\
\hline Grape (ii) & ND & $0.032 \pm 0.001^{\mathrm{c}}$ & ND & ND & $0.024 \pm 0.003^{\mathrm{h}}$ & ND & ND & ND \\
\hline Mandarin & $0.935 \pm 0.074^{\mathrm{b}}$ & $0.033 \pm 0.001^{\mathrm{c}}$ & $0.063 \pm 0.003^{\mathrm{d}}$ & $0.098 \pm 0.006^{\mathrm{e}}$ & ND & ND & ND & ND \\
\hline Pomegranate & $0.258 \pm 0.051^{\mathrm{a}}$ & $0.030 \pm 0.001^{\mathrm{c}}$ & $0.092 \pm 0.005^{\mathrm{d}}$ & ND & ND & ND & ND & ND \\
\hline Tomatoes & ND & $0.033 \pm 0.002^{\mathrm{c}}$ & ND & $0.162 \pm 0.075^{\mathrm{g}}$ & $0.016 \pm 0.002^{\mathrm{h}}$ & ND & ND & ND \\
\hline AC in fruits $(\mathrm{n}=10)$ & $0.579 \pm 0.085$ & $0.031 \pm 0.001$ & $0.039 \pm 0.006$ & $0.049 \pm 0.005$ & $\mathrm{NC}$ & $\mathrm{NC}$ & $\mathrm{NC}$ & $\mathrm{NC}$ \\
\hline
\end{tabular}

Results are expressed as mean \pm standard deviation, $\mathrm{n}$ is the number of samples, Means in the same column followed by the same letter are not significantly different at $95 \%$ confidence level, while those with different letters are significantly different, AC is the average concentration, ND is not detected due to below the LOD of the ICP method, NC is not calculated due to below the LOD of the ICP method 
TABLE-6

AVERAGE CONCENTRATIONS OF TTES IN FRUIT, AGRICULTURAL SOIL AND WELLS WATER SAMPLES

\begin{tabular}{|c|c|c|c|c|c|c|c|c|c|}
\hline \multirow{2}{*}{ Samples } & \multicolumn{8}{|c|}{ Concentration (mg Kg${ }^{-1}$ dry weight, edible part of fruit, $\mathrm{mg} \mathrm{Kg}^{-1}$ dry weight of soil and $\mathrm{mg} \mathrm{L}^{-1}$ of water) } & \multirow{2}{*}{ Ref. } \\
\hline & $\mathrm{Al}$ & $\mathrm{Cd}$ & As & $\mathrm{Pb}$ & $\mathrm{Mn}$ & $\mathrm{Cr}$ & Co & $\mathrm{Ni}$ & \\
\hline Fruits $(\mathrm{n}=10)$ & $\begin{array}{c}0.579 \pm \\
0.085\end{array}$ & $\begin{array}{c}0.031 \pm \\
0.001\end{array}$ & $\begin{array}{c}0.039 \pm \\
0.006\end{array}$ & $\begin{array}{c}0.049 \pm \\
0.005\end{array}$ & $\mathrm{NC}$ & $\mathrm{NC}$ & $\mathrm{NC}$ & $\mathrm{NC}$ & $\begin{array}{l}\text { Present } \\
\text { study }\end{array}$ \\
\hline Soil $(n=10)$ & $\begin{array}{c}55.26 \pm \\
3.05\end{array}$ & $\mathrm{NC}$ & $\begin{array}{c}0.043 \pm \\
0.006\end{array}$ & $\begin{array}{c}0.047 \pm \\
0.004\end{array}$ & $\begin{array}{c}3.01 \pm \\
1.13\end{array}$ & $\begin{array}{c}0.24 \pm \\
0.06\end{array}$ & $\mathrm{NC}$ & $\begin{array}{c}0.147 \pm \\
0.034\end{array}$ & [18] \\
\hline Wells water $(n=15)$ & 0.015 & 0.006 & 0.032 & 0.015 & $\mathrm{NC}$ & $\mathrm{NC}$ & $\mathrm{NC}$ & $\mathrm{NC}$ & {$[18,34]$} \\
\hline
\end{tabular}

Results are expressed as mean \pm standard deviation, Sps is the number of samples, AC is the average concentration, NC is not calculated due to below the LOD of the ICP method.

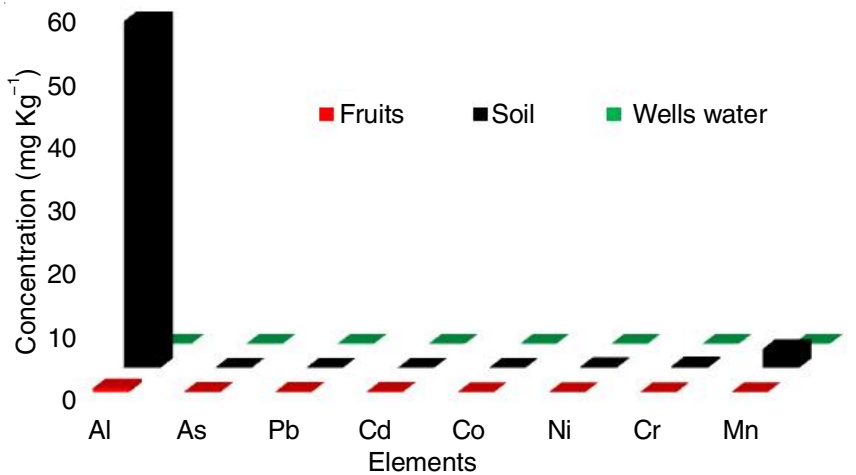

Fig. 2. A bar plot of TTEs average contents in fruit, agricultural soil and wells water samples

it could be suggested that $\mathrm{Pb}$ found in different samples originated from atmospheric deposition. This may also be due to the vehicular lead emission could be likely source of lead pollution in areas close to agricultural fields. On contrary, in all fruit samples, the uptake and the accumulation of Mn was relatively low. However, generally speaking, we can say that the concentration of studied TTEs in fruits from Turabah valley are below the permissible concentrations given for fruits.

\section{Conclusion}

The analytical parameters of microwave oven and ICP method were extensively studied and well validated. This method was applied for the determination of selected TTEs in fresh fruit samples from Turabah valley of Saudi Arabia. The obtained values of TTEs were within the limits that recommended by the FAO/WHO/SASO. The elevated level of Al may not cause harmful effects to health for the time been, but careful attention must be taken in the coming future. In addition, the presence of $\mathrm{Cd}, \mathrm{As}$ and $\mathrm{Pb}$ in some fruits indicates that there may be a translocation of those elements from the irrigation water and/ or soil and/or atmosphere. For this reasons, the source of pollutions in Turabah valley should be strictly monitored for protecting the health of riverine ecosystems along with fruits.

\section{ACKNOWLEDGEMENTS}

The authors gratefully thanks Dean of Deanship of Scientific Research, Taif University, Saudi Arabia, for sponsoring this project [Project number: 5552-438-1].

\section{CONFLICT OF INTEREST}

The authors declare that there is no conflict of interests regarding the publication of this article.

\section{REFERENCES}

1. A. Momen, G. Zachariadis, A. Anthemidis and J. Stratis, Talanta, 71, 443 (2007); https://doi.org/10.1016/j.talanta.2006.04.018

2. A. Agarwal, P. Khanna, D.K. Baidya and M.K. Arora, J. Endocrinol. Metabol., 1, 57 (2011); https://doi.org/10.4021/jem24e.

3. M.A.A. Elsheikh, M.H.H. Mahmoud and A.A. Momen, Orient. J. Chem., 33, 2263 (2017); https://doi.org/10.13005/ojc/330514.

4. A.M. Basha, N. Yasovardhan, S.V. Satyanarayana, G.V.S. Reddy and A. Vinod Kumar, Toxicol. Rep., 1, 505 (2014); https://doi.org/10.1016/j.toxrep.2014.07.011.

5. S. Yami, B. Chandravanshi, T. Wondimu and C. Abuye, Springerplus, 5, 747 (2016); https://doi.org/10.1186/s40064-016-2382-3.

6. T.F. Mehari, L.V. Greene, A.L. Duncan and S.O. Fakayode, J. Environ. Prot., 6, 573 (2015); https://doi.org/10.4236/jep.2015.66052.

7. K. Sharma, M. Agrawal and M. Marshall, Food Chem. Toxicol., 47, 583 (2009); https://doi.org/10.1016/j.fct.2008.12.016

8. M.A. Radwan and A.K. Salama, Food Chem. Toxicol., 44, 1273 (2006); https://doi.org/10.1016/j.fct.2006.02.004.

9. M. Sager, J. Food Sci. Eng., 7, 239 (2017). https://doi.org/10.17265/2159-5828/2017.05.002.

10. D. Todea, O. Cadar, D. Simedru, C. Roman, C. Tanaselia, I. Suatean and A. Naghiu, Not. Bot. Horti. Agrobo., 42, 523 (2014); https://doi.org/10.15835/nbha4229715.

11. S. Abdrabo, G. Grindlay, L. Gras and J. Mora, Food Anal. Methods, 8, 1268 (2015); https://doi.org/10.1007/s12161-014-0011-8.

12. N. Taharn, S. Techawongstein and S. Chanthai, Int. Food Res. J., 21, 517 (2014).

13. G. Mausi, G. Simiyu and S. Lutta, Kenyan J. Environ. Earth Sci., 4, 1 (2014).

14. F.C. Bressy, G.B. Brito, I.S. Barbosa, L.S.G. Teixeira and M.G.A. Korn, Microchem. J., 109, 145 (2013); https://doi.org/10.1016/j.microc.2012.03.010.

15. A. Igwegbe, C. Agukwe and C. Negbenebor, Res. Inv. Int. J. Eng. Sci. 2, 1 (2013).

16. M.H.H. Ali and K.M. Al-Qahtani, Egypt. J. Aquat. Res., 38, 31 (2012); https://doi.org/10.1016/j.ejar.2012.08.002.

17. M. Aldjain, H. Al-Whaibi, S. Al-Showiman and H. Siddiqui, Saudi J. Biol. Sci., 18, 175 (2011); https://doi.org/10.1016/j.sjbs.2010.12.001.

18. M. Elsheikh, D. Ali, A. Momen and M. Khalid, Int. J. Multidiscipl. Curr. Res., 3, 13 (2015).

19. H. Inuwa, V. Aina, G. Baba, I. Aimola and V. Thompson, Br. J. Dairy Sci., 2, 27 (2011).

20. A. Momen, M. Mahmoud, D. Hag Ali, S. Alotaibi, M. Elsheikh and M. Khalid, Sci. Technol. Publ. Policy, 2, 26 (2018); https://doi.org/10.11648/j.stpp.20180202.12.

21. C. Bressy, B. Brito, S. Barbosa, G. Teixeira and A. Korn, Microchem. J., 109, 145 (2013); https://doi.org/10.1016/i.microc.2012.03.010. 
22. A. Momen, G. Zachariadis, A. Anthemidis and J. Stratis, Anal. Chim. Acta, 565, 81 (2006); https://doi.org/10.1016/j.aca.2006.01.104.

23. AOAC, Association of Official Analytical Chemists, Official Methods of Analysis of AOAC International, JAOAC Int., $21^{\text {st }}$ edn., vol. 1 (2019).

24. F. Francis, Wiley Encyclopedia of Food Science and Technology, John Wiley \& Sons, Inc.: New York, edn 2 (1999).

25. J. Miller and J. Miller, Statistics and Chemometrics for Analytical Chemistry, Trans-Atlantic Publs Inc. Pearson Education Limited: England, edn 6 (2010).

26. L. Hellen, F. Christina and C. Othman, J. Food Nutr. Sci., 2, 277 (2014). https://doi.org/10.11648/j.jfns.20140206.16.

27. K. Taha and F. Al-Ghtani, World Scientific News, 12, 125 (2015).

28. E. Assirey, J. Taibah Univ. for Sci., 9, 75 (2015); https://doi.org/10.1016/j.jtusci.2014.07.002.

29. M. Elbagermi, H. Edwards and A. Alajtal, Int. Sch. Res. Net. Anal. Chem., Article ID 827645 (2012); https://doi.org/10.5402/2012/827645.
30. O. Ekpete, O. Edori and E. Fubara, Br. J. Appl. Sci. Technol., 3, 1447 (2013); https://doi.org/10.9734/BJAST/2014/4431.

31. E. Chuku and N. Akani, IIARD Int. J. Biol. Medical Res., 1, 1 (2015).

32. P. Priyanka, H. Sayed, A. Joshi, B. Jadhav and P. Chilkawar, Afr. J. Food Sci., 7, 428 (2013); https://doi.org/10.5897/AJFS2013.1037.

33. S. Al-Maiman and D. Ahmad, Food Chem., 76, 437 (2002); https://doi.org/10.1016/S0308-8146(01)00301-6.

34. A. Rahman, L. Kandpal, S. Lohumi, M. Kim, H. Lee, C. Mo and B. Cho, Appl. Sci., 7, 109 (2017); https://doi.org/10.3390/app7010109.

35. Environmental Agency, Science Report - Updated Technical Background to the CLEA model, Almondsbury, Bristol, UK (2009). 